"Sustainability reporting: An overview of the recent development"

\begin{tabular}{|c|c|c|}
\hline \multirow{3}{*}{ AUTHORS } & \multicolumn{2}{|l|}{ Inten Meutia (iD) } \\
\hline & \multicolumn{2}{|l|}{ Zulnaidi Yaacob (i) } \\
\hline & \multicolumn{2}{|l|}{ Shelly F. Kartasari (iD } \\
\hline ARTICLE INFO & \multicolumn{2}{|c|}{$\begin{array}{l}\text { Inten Meutia, Zulnaidi Yaacob and Shelly F. Kartasari (2020). Sustainability } \\
\text { reporting: An overview of the recent development. Accounting and Financial } \\
\text { Control, 3(1), 23-39. doi:10.21511/afc.03(1).2020.03 }\end{array}$} \\
\hline DOI & \multicolumn{2}{|c|}{ http://dx.doi.org/10.21511/afc.03(1).2020.03 } \\
\hline RELEASED ON & \multicolumn{2}{|l|}{ Thursday, 17 June 2021} \\
\hline RECEIVED ON & \multicolumn{2}{|l|}{ Wednesday, 03 March 2021} \\
\hline ACCEPTED ON & \multicolumn{2}{|l|}{ Friday, 28 May 2021} \\
\hline & \multicolumn{2}{|l|}{$(\mathrm{cc}) \mathrm{EY}$} \\
\hline LICENSE & \multicolumn{2}{|c|}{$\begin{array}{l}\text { This work is licensed under a Creative Commons Attribution } 4.0 \text { International } \\
\text { License }\end{array}$} \\
\hline JOURNAL & \multicolumn{2}{|l|}{ "Accounting and Financial Control" } \\
\hline ISSN PRINT & \multicolumn{2}{|l|}{$2543-5485$} \\
\hline ISSN ONLINE & \multicolumn{2}{|l|}{$2544-1450$} \\
\hline PUBLISHER & \multicolumn{2}{|c|}{ LLC "Consulting Publishing Company "Business Perspectives" } \\
\hline FOUNDER & \multicolumn{2}{|c|}{ Sp. z o.o. Kozmenko Science Publishing } \\
\hline$\sigma^{0}$ & 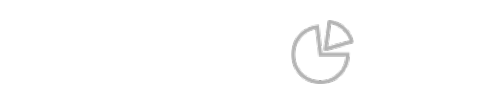 & ニニこ \\
\hline NUMBER OF REFERENCES & NUMBER OF FIGURES & NUMBER OF TABLES \\
\hline 73 & 9 & 4 \\
\hline
\end{tabular}

(c) The author(s) 2023. This publication is an open access article. 


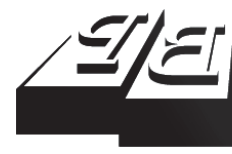

\section{BUSINESS PERSPECTIVES}

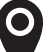

LLC "CPC "Business Perspectives" Hryhorii Skovoroda lane, 10, Sumy, 40022, Ukraine www.businessperspectives.org
Received on: $3^{\text {rd }}$ of March, 2021 Accepted on: $28^{\text {th }}$ of May, 2021 Published on: $17^{\text {th }}$ of June, 2021

(C) Inten Meutia, Zulnaidi Yaacob, Shelly F. Kartasari, 2021

Inten Meutia, Ph.D., Associate Professor, Economic Faculty, Accounting Department, University Sriwijaya, Indonesia. (Corresponding author)

Zulnaidi Yaacob, Ph.D., Associate Professor, Management Section, School of Distance Education, Universiti Sains Malaysia, Malaysia

Shelly F. Kartasari, Ph.D., Lecturer, Economic Faculty, Accounting Department, University Sriwijaya, Indonesia.

\title{
SUSTAINABILITY REPORTING: AN OVERVIEW OF THE RECENT DEVELOPMENT
}

\begin{abstract}
This study aims to provide an extensive overview of the current state of sustainability reporting through the review studies on sustainability reports (SR) in the accounting literature for the period 2015-2020. A structured literature review (SLR) methodology is used to investigate how the SR literature develops and focuses. The study uses keywords such as "sustainability report" and "sustainability reporting" to identify studies that are relevant to a given topic. A total of 44 published studies were found. This study identifies the main directions of SR research in the 2015-2020 period and discusses several important aspects of research, namely methodology, research methods, and the theory used. To enrich the results, this study defines the scope, country of research, topics and sectors studied. The study provides insight into future SR research used by researchers to develop SR research. Several things are proposed that can be used as a guide for future SR research, such as sustainability in SMEs and the public sector. Ensuring sustainability is one of the research topics that can be a direction for researchers in the future. Theories such as contingency and source credibility can be an alternative to explaining the reality of sustainability reporting.
\end{abstract}

Keywords

JEL Classification sustainability report, sustainability reporting sustainability performance

Q56, M40

\section{INTRODUCTION}

Sustainability reporting (SR) is a new paradigm shift that is not only related to disclosure, but also integrates with the communication process between companies and stakeholders. This process provides stakeholders with an opportunity to determine if the company has taken their interests into account when making decisions (Frynas \& Yamahaki, 2016). The increasing attention of companies to sustainability reporting globally has been reported (KPMG \& UNEP, 2006; KPMG, 2008; Lynch et al., 2014; Anunciação et al., 2017; LarrinagaGonzalez, 2007; Adams \& Frost, 2008). Scientific research in this area has also developed significantly where the quality of sustainability reporting is the subject of research and benchmarking studies (Milne \& Gray, 2013; Arayssi et al., 2016; Rezaee, 2016; Kolk, 2004).

Researchers continuously examine sustainability reporting to contribute to the development of SR. Nevertheless, almost all studies were carried out in the western and developed countries such as the USA, Canada, the UK, Australia, or New Zealand (Journeault et al., 2020; Safari \& Areeb, 2020; Kaur \& Lodhia, 2018; Crifo et al., 2019; Michelon et al., 2019). For this reason, in many European countries, a sustainability report is mandatory for many companies.

Meanwhile, in Asia, studies on sustainability reports are mostly carried out in developed countries such as China (Dong et al., 2020; Li et al., 2013), Malaysia (Jamil et al., 2020), Thailand (Petcharat \& Zaman, 
2019), while in other Asian countries, SR research is still very few such as Pakistan (Bae et al., 2018), India (Aggarwal \& Singh, 2019), and Indonesia (Amidjaya \& Widagdo, 2019; Meutia et al., 2018). Bae et al. (2018) state that there are few studies on sustainability reporting in Asian countries. Besides, several researchers have also identified SR practices in the public sector (Adams et al., 2014; Gazzola et al., 2019; Montecalvo et al., 2018; Farneti et al., 2019).

Given the importance of sustainability reporting in accounting research, this study provides a comprehensive review of existing research over the past six years. The study continues the studies conducted by Dienes et al. (2016). It tries to make a systematic SR study by questioning the factors driving sustainability reporting. The research sample is 516 studies on sustainability reporting published in Englishlanguage journals for 16 years (2000-2015). The study seeks to refine Dienes's research by focusing on SR studies that are published in accounting journals and those related to sustainability. Besides, Dienes's study mixed the terminology of CSR (Corporate Social Responsibility Reporting) and SR (Sustainability Reporting). Although these two terms appear similar, there are conceptual differences between CSR and SR (Schnepp \& Bowen, 1954).

The social responsibility of entrepreneurs as "the obligation of businessmen to make policies, carry out these decisions, and follow actions consistent with the goals and values in our society" (Bowen, 2013, p. 6). According to Carroll (1979, p. 500), "The social responsibility of business encompasses the economic, legal, ethical, and discretionary expectations that society has of organizations at a given point in time." CSR means more than just obeying the law; Just complying with the law cannot be considered a CSR activity. Some examples of CSR actions adopt pro-gender human resource management programs, non-discrimination, energy-saving, recycling, and pollution reduction, supporting micro and local businesses' development, including creating products with local wisdom (Carroll, 2009, p. 23).

Historically, sustainability was not an unknown concept in the business world. Many organizations have used this concept to achieve long-term economic and social stability for a company and an expression of good corporate citizenship. Thus, this concept has been generalized as the basis for the theory of good corporate citizenship. It refers to the narrow concept of economic profitability and considers a company's social and environmental sustainability. The fact that sustainability represents good corporate citizenship means that the company is aware of and agrees to comply with society's interests by considering future generations, nature, and the environment in every company's decision making.

This review contributes to the following accounting literature. This study focuses on sustainability reporting in accounting, management and business journals, especially those related to sustainability from 2015 to 2020. It is crucial to capture the direction of the SR research development, especially in accounting, management, and business. The literature review will highlight the various methodologies used, the theoretical basis of the study, the sustainability literature's limitations, and provide recommendations for future research.

\section{LITERATURE REVIEW}

This study uses a literature review approach because, according to Massaro et al. (2016), a literature review contributes to developing research lines and questions based on previous research findings. To offer useful insights and critiques to evaluate, identify, and discuss possible future SR research agendas, this study adopts the SLR method: "An SLR is a method for studying a corpus of scholarly literature, to develop insights, critical reflections, future research paths, and research questions" (Massaro et al., 2016, p. 3).

"SLR is a method for examining the corpus of scientific literature, for developing insights, critical reflection, future research paths, and research questions" (Dumay et al., 2016, p. 167). As it is commonly used in scientific fields that mostly utilize a quantitative approach, it is also possible to imple- 
ment SLR in accounting studies. Several studies in accounting using SLRs are noted, among them are (Dumay et al., 2016; Bracci et al., 2019; Spence et al., 2010; Anessi-Pessina et al., 2016; Khlif \& Achek, 2017).

A systematic review uses a search methodology that "makes use of an iterative and incremental procedure in which relevant articles were searched, checked and reviewed for relevance until the whole review is completed" (Massaro et al., 2016, p. 7). Hahn and Kühnen (2013, p. 8) suggest five necessary steps for systematic literature reviews:

1) Research question: The first important step in SLR is to define a research question.

2) Material collection: The second step is to collect the articles to be reviewed. For that, the journal and the targeted keywords are determined.

3) Selection and evaluation: The next step is to evaluate relevant articles from the source. Keywords are used to filter the articles by identifying the title and reading the paper abstract.

4) Descriptive analysis and synthesis: Discussing formal aspects concerning the chosen theme to obtain valid results. The purpose of this analysis is to categorize the results of each article into consistent chunks by explaining how they relate to one another. For this reason, it is necessary to record the details of each article.

5) Results: To complement the literature review process, the findings on critical points of concern in the research question are discussed. Besides, an essential function of SLR is to present future research areas.

According to Massaro et al. (2016, p. 4), “...researchers use SLR to map and assess the existing intellectual territory to identify future research needs." For this reason, it is essential to review and criticize existing studies before offering research gaps in the future. To develop further research, Massaro et al. (2016) propose to use three critical research tasks based on Alvesson and Sandberg (2011), namely, 'insight,' 'criticism' and 'transformative redefinition' ask three generic research ques- tions and adaptable as needed to do SLR. Next, the study adopted three general research questions to focus specifically on the SR literature.

1) How is $S R$ research developing?

2) What is the focus and methodology of the SR literature?

3) What is the future for SR research?

\section{RESEARCH FRAMEWORK}

Using a systematic process, manual and electronic searches are combined to determine the papers reviewed in this study. In the first stage, the keywords such as sustainability, sustainability report, sustainability reporting are used to find articles in English-language journals in the Emerald database, EBSCOhost, ProQuest and Science Direct for the period 2015 to 2020. This paper only includes academic publications in the search process, non-academic publications are excluded from this scope. Although the use of this keyword initially gave quite a lot of results, some papers were ignored because they only covered environmental or social aspects, so it was not quite appropriate to discuss sustainability. In addition, some papers also do not specifically discuss sustainability reports. Conceptual writing is included in the database of this study, as long as it discusses the sustainability reporting. The analysis eventually reached a total of 44 publications.

Categorizing the unit of analysis is a useful strategy in identifying and exploring theoretical understanding in reviewing articles. For this reason, this study clustered the analysis based on important aspects of research, namely methodology, research methods, and theory as a basis for SR research, and the scope of research. To enrich the results of the review, this study also clustered research countries, SR topics of research concern, and sectors that were the object of research.

Figure 1 provides the research methodology used in this systematic literature review.

In the first stage, the study recorded bibliographical data from each article consisting of an author, year of publication, title, and journal. In the first 


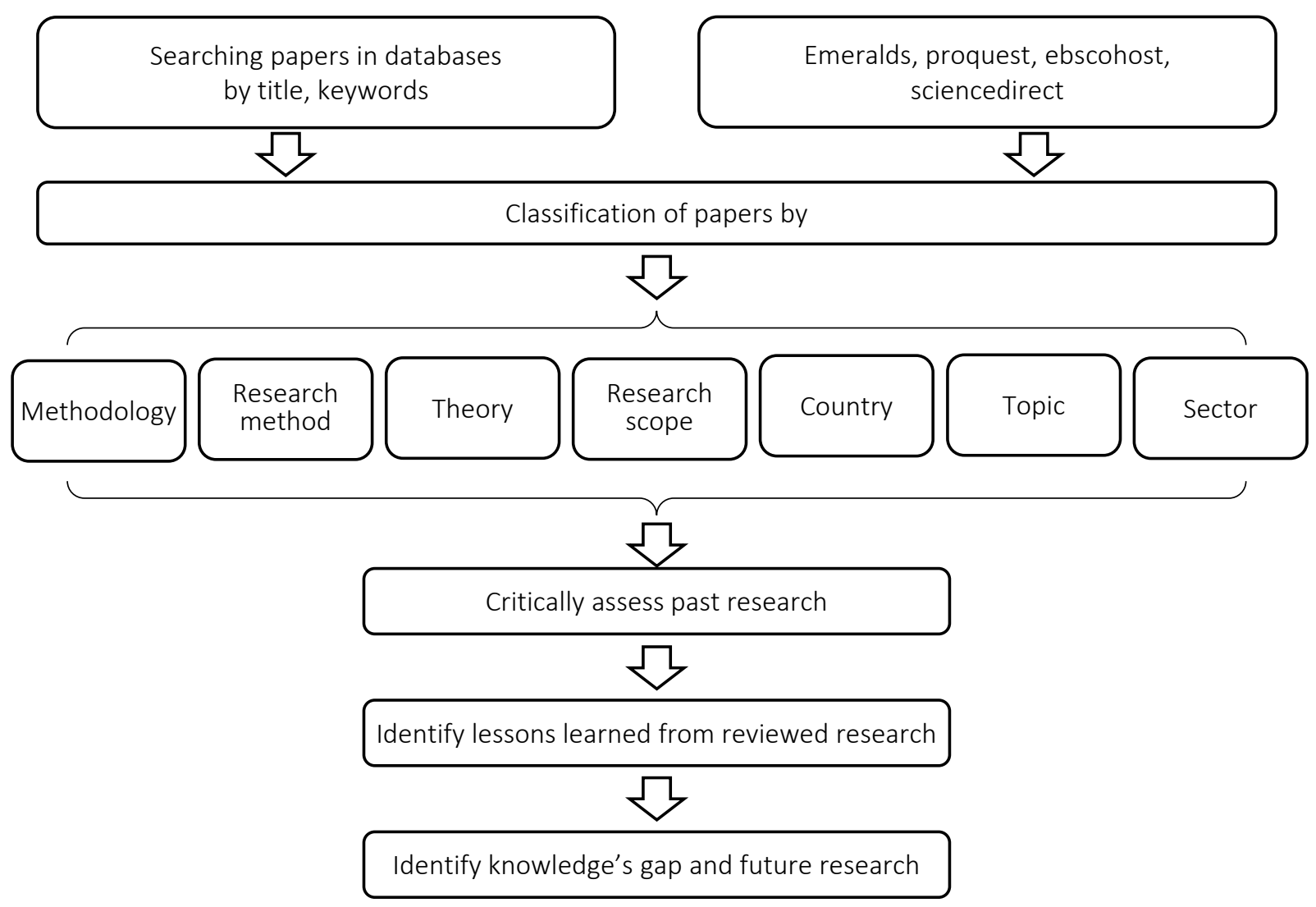

Figure 1. Literature review research methodology

Table 1. Number of sustainability studies in each journal

\begin{tabular}{|c|c|c|c|}
\hline No. & Journals & No. of studies & Percentage \\
\hline 1 & Accounting Forum & 2 & $5 \%$ \\
\hline 2 & Accounting, Auditing \& Accountability Journal & 1 & $2 \%$ \\
\hline 3 & Corporate Social Responsibility and Environmental Management & 1 & $2 \%$ \\
\hline 4 & Critical Perspectives on Accounting & 3 & $7 \%$ \\
\hline 5 & European Accounting Review & 1 & $2 \%$ \\
\hline 6 & International Journal of Sustainability in Higher Education & 2 & $5 \%$ \\
\hline 7 & Journal of Accounting in Emerging Economies & 1 & $2 \%$ \\
\hline 8 & Journal of Applied Accounting Research & 2 & $5 \%$ \\
\hline 9 & Journal of Asia Business Studies & 1 & $2 \%$ \\
\hline 10 & Journal of Applied Accounting Research & 2 & $5 \%$ \\
\hline 11 & Journal of Business Ethics & $11 *$ & $25 \%$ \\
\hline 12 & Journal of Business Research & 1 & $2 \%$ \\
\hline 13 & Journal of Financial Reporting and Accounting & 1 & $2 \%$ \\
\hline 14 & Meditari Accountancy Research & 2 & $5 \%$ \\
\hline 15 & Pacific Accounting Review & 1 & $2 \%$ \\
\hline 16 & Public Management Review & 1 & $2 \%$ \\
\hline 17 & Public Money \& Management & 1 & $2 \%$ \\
\hline 18 & Social and Environmental Accountability Journal & 1 & $2 \%$ \\
\hline 19 & Social Responsibility Journal & 4 & $9 \%$ \\
\hline 20 & Sustainability Accounting, Management and Policy Journal & 5 & $11 \%$ \\
\hline TOTAL & & 44 & $100 \%$ \\
\hline
\end{tabular}

Note: * Emerald, EBSCOhost, ProQuest, and Science Direct. 
phase of this study, 124 articles with the keywords sustainability, sustainability report and sustainability reporting were found. The next screening process is to look at journal names and read abstracts to determine whether the topics discussed are related to sustainability in a reporting or accounting context. 80 articles were excluded from the sample because they came from non-accounting journals or did not discuss the reporting aspects of sustainability. This study resulted in 44 articles for further review. As shown in Table 1, the collected papers come from leading accounting, management, and business journals such as Critical Perspectives on Accounting, Accounting Forum, Accounting, Auditing \& Accountability Journal, Journal of Accounting in Emerging Economies, Social Responsibility Journal; Journal of Business Ethics; Sustainability Accounting, Management and Policy Journal; Social and Environmental Accountability Journal. Table 1 provides the list of journals and the number of articles found based on keywords.

The first phase of this study found that most SR articles were in the Journal of Business Ethics (11 articles). It seems to be under the journals' scope that put forward ethical issues related to business. Significant numbers of articles are also found in the Sustainability Accounting, Management, and Policy Journal (five articles) and Social
Responsibility Journal (four articles). Meanwhile, other journals only have one or two articles relevant to the search keyword.

\section{DISCUSSION}

\subsection{Distribution over time}

Regarding the year of publication, Figure 2 illustrates that there was an increase in the number of papers published from 2015 to 2020 . The increase was relatively high, especially in 2018 and 2019. This trend suggests a growing interest in sustainability reporting research. The increase in SR research after 2015 may be due to the spread of the Sustainable Development Goals agenda in 2015 that were agreed upon by various countries in the world. This shows that many parties, including academics and researchers, are contributing to the achievement of the SDGs by 2030.

\subsection{Distribution by methodology and research method}

When conducting research, two methodologies can be used: qualitative and quantitative. Both of these approaches are also used in SR research. Some researchers use a qualitative approach, while others use a quantitative approach.

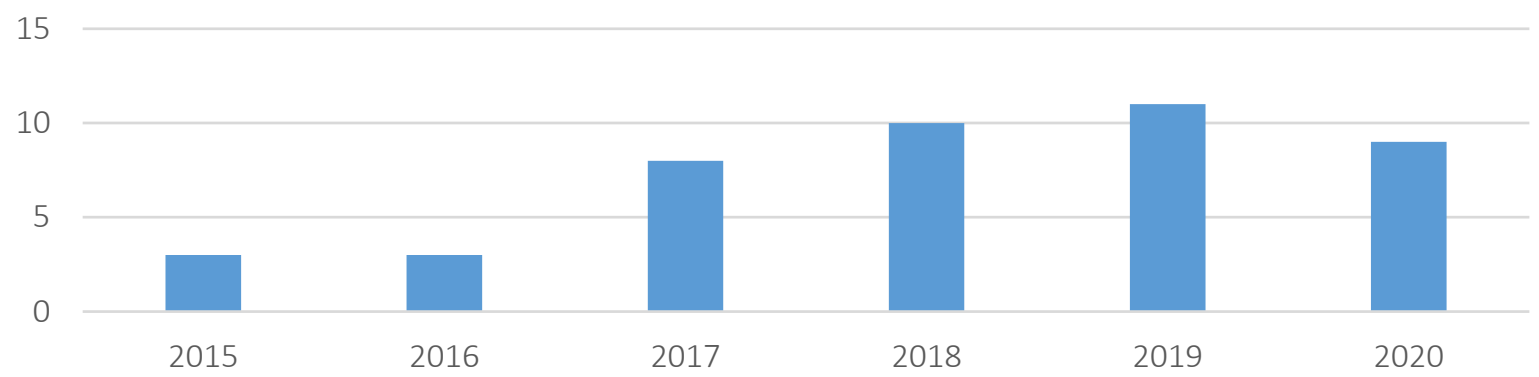

Figure 2. Year of publication

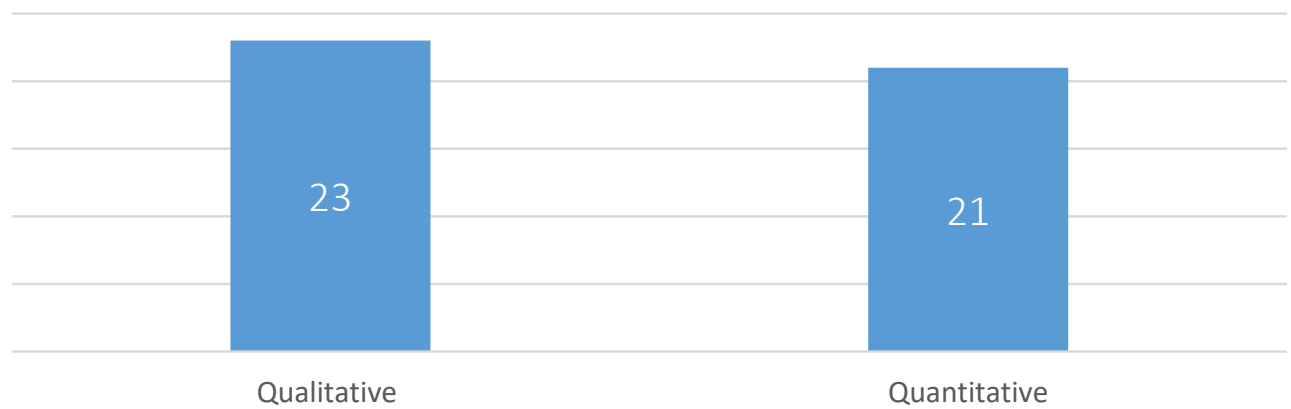

Figure 3. Research methodology 


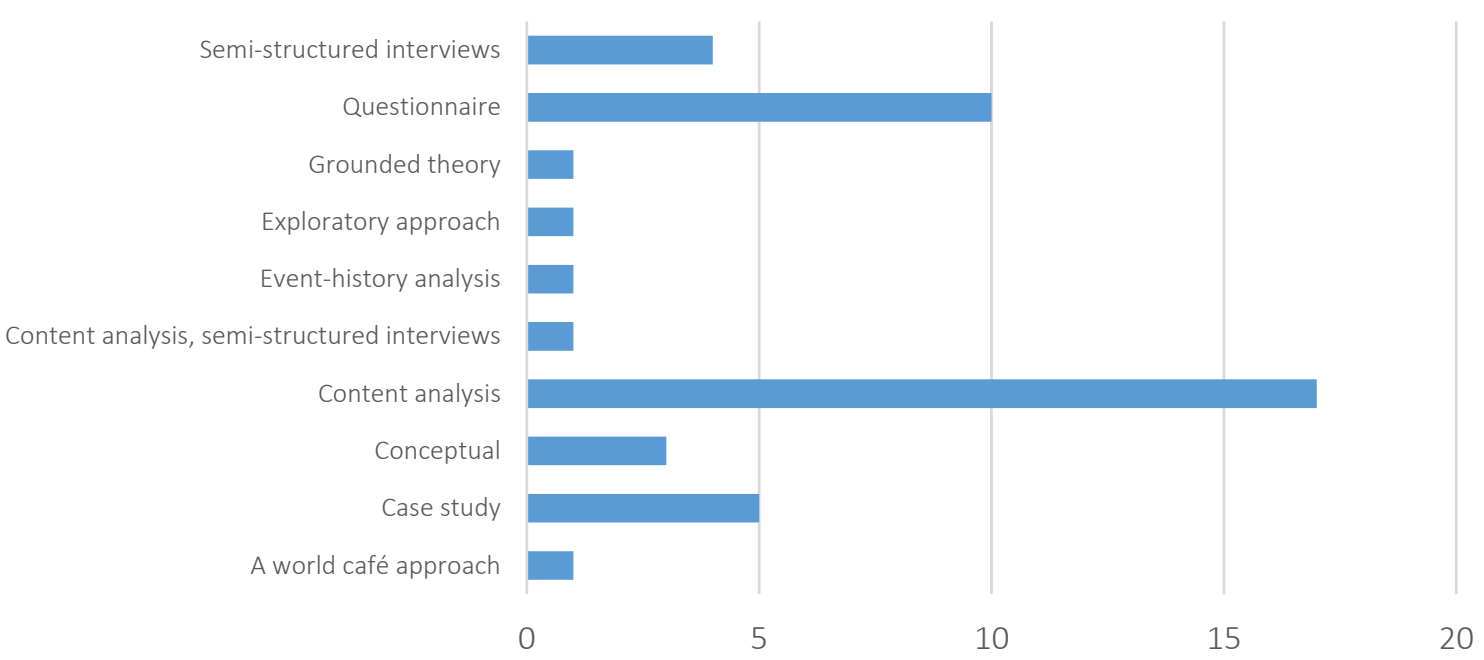

Figure 4. Research method

Figure 3 shows that both qualitative and quantitative approaches are used to study sustainability reporting. There is one conceptual paper, so it cannot be categorized as qualitative or quantitative. Of the 44 existing studies, 23 studies used a qualitative approach, and 21 studies used a quantitative approach. This review shows that sustainability report studies cannot be separated from the two research paradigms.

The next stage is to organize the types of research by reading the paper abstract. Various types of research methods are used by researchers, including:

- Survey and interview studies using questionnaires or (structured) interviews to collect data on sustainability reporting practices.

- Content analysis focuses on the content of the sustainability report. In general, the unit of analysis in this study is a sustainability report or an annual report.

- Case studies are usually carried out through observing or collecting data for one or a small number of organizations. Sustainability reporting cases are often combined with semi-structured interviews with a specific group of respondents

- A semi-structured interview is an interview without formal questions. A researcher asks more open-ended questions, allows discussion with the interviewee, and provides more comprehensive answers.
- The grounded theory means systematic inductive methods used to conduct qualitative studies for theory development.

- Event-history analysis uses observation data obtained from a company in a certain range of time that focus only on the events occurring in the observed company.

- A world café method is a simple, effective, and flexible format for accommodating extensive group discussions. It is a process that leads to not only collaborative dialogue and sharing knowledge, but also creates possibilities for action in groups of all sizes.

The characterization study of sustainability reporting is not ambiguous in any case. Several studies used a mixed-methods approach. For instance, they performed a content analysis and a semi-structured interview. For studies using a mixed-methods approach, it is presented as a separate method.

Figure 4 shows the number of articles by classification scheme type. Generally, studies on sustainability reporting in reviewed articles use content analysis (seven-ten studies), followed by questionnaires (ten studies), case studies (five studies), semi-structured interviews (four studies), and conceptual studies (three studies). Other research methods used are event-history, grounded theory, a combination of content analysis and semi-structured interviews, exploratory, and world cafe approach. Three studies are conceptual, namely Bebbington et al. (2017), Stocker et al. (2020), and Hahn et al. (2018). 
Table 2. Methodology and research method in studies

\begin{tabular}{|c|c|c|c|c|}
\hline No. & $\begin{array}{c}\text { Year of } \\
\text { publication }\end{array}$ & Authors & Methodology & $\begin{array}{l}\text { Research } \\
\text { methods }\end{array}$ \\
\hline 1 & 2015 & Lorenzo Massa, Federica Farneti, Beatrice Scappini & Qualitative & Case study \\
\hline 2 & 2015 & Heejung Byun, Tae-Hyun Kim & Quantitative & $\begin{array}{l}\text { Event-history } \\
\text { analysis }\end{array}$ \\
\hline 3 & 2016 & Shidi Dong, Lei Xu and Ron Mclver & Quantitative & Content analysis \\
\hline 4 & 2016 & Josh Wei-Jun Hsueh & Quantitative & Questionnaire \\
\hline 5 & 2016 & Nazim Hussain, Ugo Rigoni, Rene' P. Orij & Quantitative & Content analysis \\
\hline 6 & 2017 & Amanpreet Kaur, Sumit Lodhia & Qualitative & Case study \\
\hline 7 & 2017 & Habiba Al-Shaer, Mahbub Zaman & Quantitative & Questionnaire \\
\hline 8 & 2017 & Jan Bebbington, Shona Russella, Ian Thomson & Qualitative & Conceptual \\
\hline 9 & 2017 & Olivier Boiral, Inãki Heras-Saizarbitoria, Marie-Christine Brotherton & Qualitative & Content analysis \\
\hline 10 & 2017 & Samuel Drempetic, Christian Klein, Bernhard Zwergel & Quantitative & Questionnaire \\
\hline 11 & 2017 & Colin Higginsa, Samuel Tang, Wendy Stubbs & Qualitative & Content analysis \\
\hline 12 & 2017 & Katrin Hummel, Christian Schlick, Matthias Fifka & Quantitative & Questionnaire \\
\hline 13 & 2017 & Ludger Niemann, Thomas Hoppe & Qualitative & Case study \\
\hline 14 & 2018 & Remmer Sassen, Leyla Azizi & Quantitative & Content analysis \\
\hline 15 & 2018 & $\begin{array}{l}\text { Olivier Boiral, Iñaki Heras-Saizarbitoria, Marie-Christine Brotherton, } \\
\text { Julie Bernard }\end{array}$ & Qualitative & $\begin{array}{l}\text { Semi-structured } \\
\text { interviews }\end{array}$ \\
\hline 16 & 2018 & Sahar Sepasi, Udo Braendle, Amir Hossein Rahdari & Quantitative & Content analysis \\
\hline 17 & 2018 & Tricia Ong, Hadrian Geri Djajadikerta & Quantitative & Questionnaire \\
\hline 18 & 2018 & Patricia Crifo, Elena Escrig-Olmedo, Nicolas Mottis & Quantitative & Questionnaire \\
\hline 19 & 2018 & Najul Laskar & Qualitative & Content analysis \\
\hline 20 & 2018 & Carlos Larrinaga, Mercedes Luque-Vilchez, Rosa Fernández & Qualitative & Content analysis \\
\hline 21 & 2018 & Giovanna Michelon, Dennis M. Patten, Andrea M. Romi & Quantitative & Questionnaire \\
\hline 22 & 2018 & Monica Montecalvo, Federica Farneti \& Charl de Villiers & Qualitative & $\begin{array}{c}\text { Content analysis, } \\
\text { Semi-structured } \\
\text { interviews }\end{array}$ \\
\hline 23 & 2018 & Tobias Hahn, Frank Figge, Jonatan Pinkse, Lutz Preuss & Qualitative & Conceptual \\
\hline 24 & 2018 & Samanthi Silva, Edeltraud Guenther & Qualitative & $\begin{array}{l}\text { A world café } \\
\text { approach }\end{array}$ \\
\hline 25 & 2019 & Marc Journeault, Yves Levant, Claire-France Picard & Qualitative & Case study \\
\hline 26 & 2019 & Priyanka Aggarwal and Ajay Kumar Singh & Quantitative & Content analysis \\
\hline 27 & 2019 & An et al. & Qualitative & Case study \\
\hline 28 & 2019 & Amina Buallay & Quantitative & Questionnaire \\
\hline 29 & 2019 & Dinithi Dissanayake, Carol Tilt, Wei Qian & Quantitative & Content analysis \\
\hline 30 & 2019 & Prihatnolo Gandhi Amidjaya and Ari Kuncara Widagdo & Quantitative & Content analysis \\
\hline 31 & 2019 & Neungruthai Petcharat, Mahbub Zaman & Qualitative & $\begin{array}{l}\text { Semi-structured } \\
\text { interviews }\end{array}$ \\
\hline 32 & 2019 & David Talbot, Olivier Boiral & Qualitative & Content analysis \\
\hline 33 & 2019 & $\begin{array}{l}\text { Patrizia Gazzola, Stefano Amelio, Fragkoulis Papagiannis, Zenon } \\
\text { Michaelides }\end{array}$ & Quantitative & Questionnaire \\
\hline 34 & 2019 & Lina Dagiliene, Kristina Šutiene & Quantitative & Questionnaire \\
\hline 35 & 2020 & Maryam Safari, Amreen Areeb & Qualitative & $\begin{array}{l}\text { Exploratory } \\
\text { approach }\end{array}$ \\
\hline 36 & 2020 & Desi Adhariani, Elda du Toit & Qualitative & Content analysis \\
\hline 37 & 2020 & Muatasim Ismaeel, Zarina Zakaria & Qualitative & $\begin{array}{l}\text { Semi-structured } \\
\text { interviews }\end{array}$ \\
\hline 38 & 2019 & Coco Klußmann & Qualitative & Grounded theory \\
\hline 39 & 2020 & Philipp Hummel & Quantitative & Content analysis \\
\hline 40 & 2020 & Amira Jamil, Nazli Anum Mohd Ghazali and Sherliza Puat Nelson & Quantitative & Content analysis \\
\hline 41 & 2020 & Mirwais Usmani, Jane Davison \& Christopher J. Napier & Qualitative & $\begin{array}{l}\text { Semi-structured } \\
\text { interviews }\end{array}$ \\
\hline 42 & 2020 & Carol A. Tilt, Wei Qian, Sanjaya Kuruppu and Dinithi Dissanayake & Qualitative & Content analysis \\
\hline 43 & 2020 & $\begin{array}{l}\text { Fabricio Stocker, Michelle P. de Arruda, Keysa M. C. de Mascena, } \\
\text { João M. G. Boaventura }\end{array}$ & Qualitative & Conceptual \\
\hline 44 & 2020 & Edward Millar, Cory Searcy & Quantitative & Content analysis \\
\hline
\end{tabular}




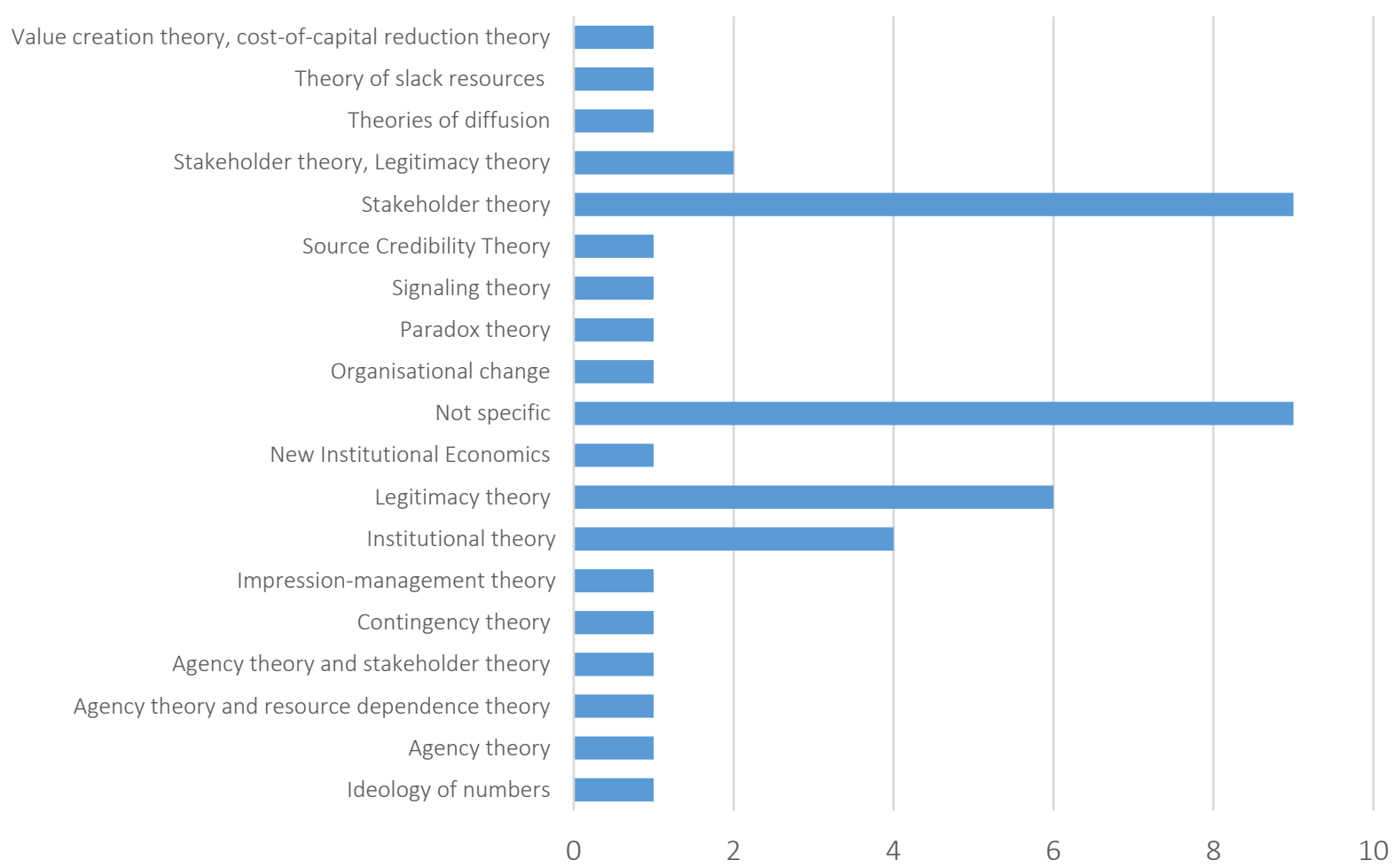

Figure 5. Research theories

\subsection{Research theory}

Figure 5 describes the theories used in the study of sustainability reporting during the review period. Nine articles do not explicitly state the theory used in the study. Stakeholder theory is one of the most widely used approaches in the previous literature to explain sustainability reporting (Safari \& Areeb, 2020; Kaur \& Lodhia, 2018; Al-Shaer \& Zaman, 2019; Sassen \& Azizi, 2018; Ong \& Djajadikerta, 2018; Dissanayake et al., 2019). According to stakeholder theory, companies have responsibilities towards other groups with interests in the company apart from shareholders (Freeman, 1984). Following what was reported by Spence et al. (2010), researchers describe stakeholder theory as the dominant and most useful theory in explaining the practice of sustainability reporting.

Apart from stakeholder theory, legitimacy theory is also the basis for several researchers in discussing SR (Aggarwal \& Singh, 2019; Boiral et al., 2019; Michelon et al., 2019; Petcharat \& Zaman, 2019; Talbot \& Boiral, 2018; Usmani et al., 2020). The legitimacy theory explains the existence of a contract between a company and the community, which forces the company to comply with social norms to ensure its sustainability and society. SR provides le- gitimacy for corporate action by firmly influencing public perceptions and helping to avoid unexpected publication (Lanis \& Richardson, 2012; Bebbington et al., 2008; Archel et al., 2009). Two articles use both theories together, namely the stakeholder theory and the legitimacy theory (An et al., 2019; Klußmann et al., 2019).

Apart from these two theories, another theory used by researchers is the institutional theory (Dong et al., 2020; Ismaeel \& Zakaria, 2020; Montecalvo et al., 2018; Dissanayake et al., 2019). Institutional theory explains how organizations can adopt certain organizational forms to conform to institutionalized norms or rules to gain legitimacy in the context in which they operate. According institutional theory, organizations carry out their activities by adopting homogeneous forms of behavior from other organizations. Sustainability reporting is the homogeneous behavior of a group of organizations, reflecting conformity with institutionalized norms or rules formed by isomorphic mechanisms (Shabana et al., 2017). The institutional theory also shares the same views as the stakeholder theory. External pressure, power, and legitimacy, and other sources of influence are also discussed in studies of stakeholder relations (Majoch et al., 2017). 
Table 3. Theories in studies

Source: Data analyzed.

\begin{tabular}{|c|c|c|}
\hline Theory & Author(s) & Year \\
\hline \multirow{10}{*}{ Stakeholder Theory } & Maryam Safari, Amreen Areeb & 2020 \\
\hline & Amanpreet Kaur, Sumit Lodhia & 2018 \\
\hline & Habiba AIShaer, Mahbub Zaman & 2017 \\
\hline & Remmer Sassen, Leyla Azizi & 2018 \\
\hline & Tricia Ong, Hadrian Geri Djajadikerta & 2018 \\
\hline & Dinithi Dissanayake, Carol Tilt, Wei Qian & 2019 \\
\hline & Fabricio Stocker, Michelle P. de Arruda, Keysa M. C. de Mascena, João M. G. Boaventura & 2020 \\
\hline & Patrizia Gazzola, Stefano Amelio, Fragkoulis Papagiannis, Zenon Michaelides & 2019 \\
\hline & Edward Millar, Cory Searcy & 2020 \\
\hline & Dinithi Dissanayake, Carol Tilt, Wei Qian & 2019 \\
\hline \multirow{4}{*}{ Legitimacy Theory } & Giovanna Michelon, Dennis M. Patten, Andrea M. Romi & 2018 \\
\hline & Neungruthai Petcharat, Mahbub Zaman & 2019 \\
\hline & David Talbot, Olivier Boiral & 2019 \\
\hline & Mirwais Usmani, Jane Davison, Christopher J. Napier & 2020 \\
\hline Signaling Theory & Katrin Hummel, Christian Schlick, Matthias Fifka & 2017 \\
\hline \multirow{5}{*}{ Institutional Theory } & Shidi Dong, Lei Xu and Ron Mclver & 2016 \\
\hline & Muatasim Ismaeel, Zarina Zakaria & 2020 \\
\hline & Monica Montecalvo, Federica Farneti \& Charl de Villiers & 2018 \\
\hline & Philipp Hummel & 2020 \\
\hline & Carol A. Tilt, Wei Qian, Sanjaya Kuruppu and Dinithi Dissanayake & 2020 \\
\hline \multirow{2}{*}{ Agency Theory } & Patricia Crifo, Elena EscrigOlmedo, Nicolas Mottis & 2018 \\
\hline & Amira Jamil, Nazli Anum Mohd Ghazali and Sherliza Puat Nelson & 2020 \\
\hline \multirow{2}{*}{$\begin{array}{l}\text { Stakeholder - Legitimacy } \\
\text { Theory }\end{array}$} & Yi An et al & 2019 \\
\hline & Coco Klußmann & 2019 \\
\hline Ideology of numbers & Marc Journeault, Yves Levant, Claire-France Picard & 2019 \\
\hline Impression-management & Desi Adhariani, Elda du Toit & 2020 \\
\hline Value creation Theory & Amina Buallay & 2019 \\
\hline Organizational change & Lorenzo Massa, Federica Farneti, Beatrice Scappini & 2015 \\
\hline Slack resources Theory & Samuel Drempetic, Christian Klein, Bernhard Zwergel & 2017 \\
\hline Source Credibility Theory & Josh Wei-Jun Hsueh & 2016 \\
\hline Theories of diffusion & Heejung Byun, Tae-Hyun Kim & 2015 \\
\hline Paradox Theory & Tobias Hahn, Frank Figge, Jonatan Pinkse, Lutz Preuss & 2018 \\
\hline Contingency Theory & Lina Dagiliene, Kristina Šutiene & 2019 \\
\hline
\end{tabular}

A review of the theory used in SR research shows that several theories can be used as alternatives in explaining SR, such as the ideology of numbers theory (Journeault et al., 2020), paradox theory (Hahn et al., 2018), source credibility theory (Hsueh, 2018), and the theory of diffusion (Byun \& Kim, 2017). Using these various theories in SR research will provide a new perspective in observing the SR phenomenon.

\subsection{Study scope}

The research scope is also a concern in this study to determine the previous researchers' concerns. Seventeen studies discuss SR in the international area, twenty-five studies discuss SR in the national scope, and two studies discuss SR topics in the local area. SR research in the local area is

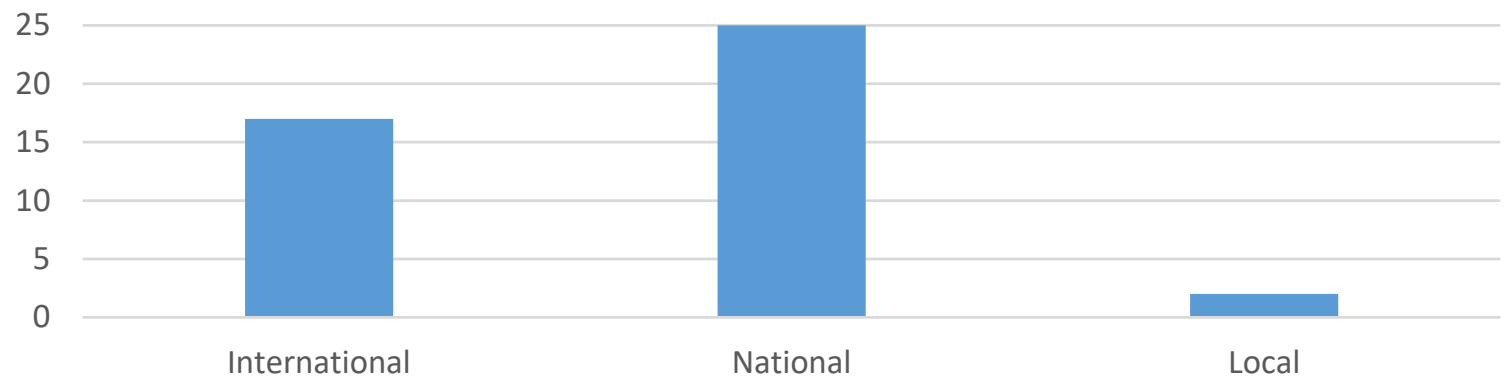

Figure 6 . The scope of studies 
in case studies on local government in Australia (Kaur \& Lodhia, 2018) and SMEs in Italia (Massa et al., 2015).

\subsection{Research country}

Developed countries are sovereign countries with economic conditions and technologically advanced infrastructure. Developed countries are also supported by the Human Development Index, political stability, gross domestic product (GDP), industrialization, and high freedom. Countries that have not reached the standards of developed countries are called developing countries.

Seventy percent of SR research is conducted in developed countries, while thirty percent in developing countries. Figure 7 shows that companies in developed countries more widely practice SR practices compared to developing countries. This finding is consistent with Soh (2014), who states that SR research is more prevalent in developed countries.

Of the 27 studies conducted at the national and local levels, the most research was conducted in the US and Australia, each with four studies. Research in the USA was led by Sassen and Azizi (2018), Hussain et al. (2018), Michelon et al. (2019), Millar and Searcy (2020). Meanwhile, research in Australia was conducted by Safari and Areeb (2020), Kaur and Lodhia (2018), Ong and Djajadikerta (2018), Higgins et al. (2020).

\subsection{Research topic}

This study identifies 28 topics dealing with the various issues related to sustainability report research. An issue that has attracted a lot of attention from SR researchers is governance and identification of factors influencing SR. The topic of governance is in studies by Ong and Djajadikerta

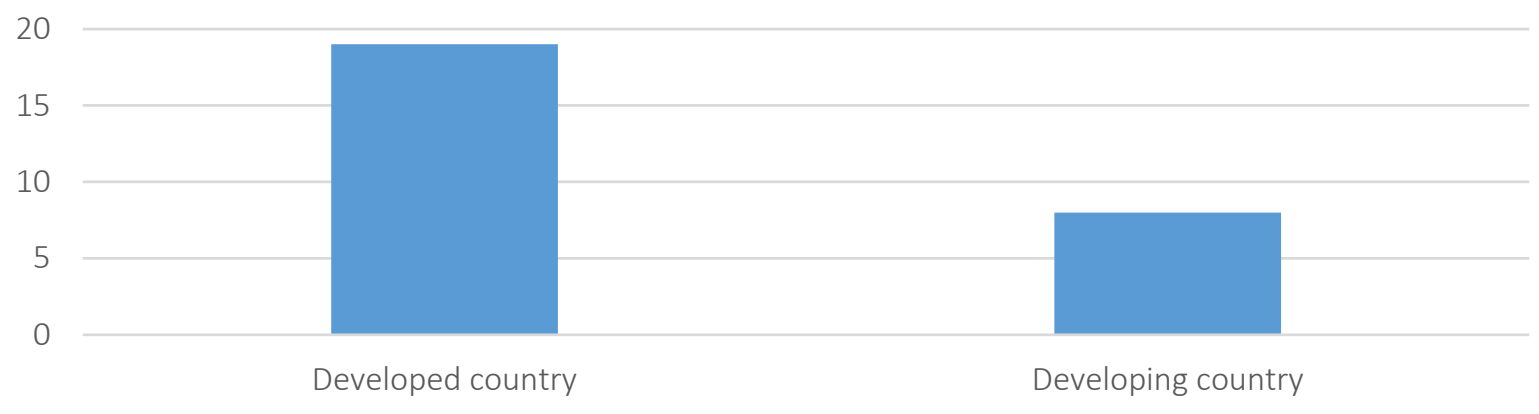

Figure 7. Country category

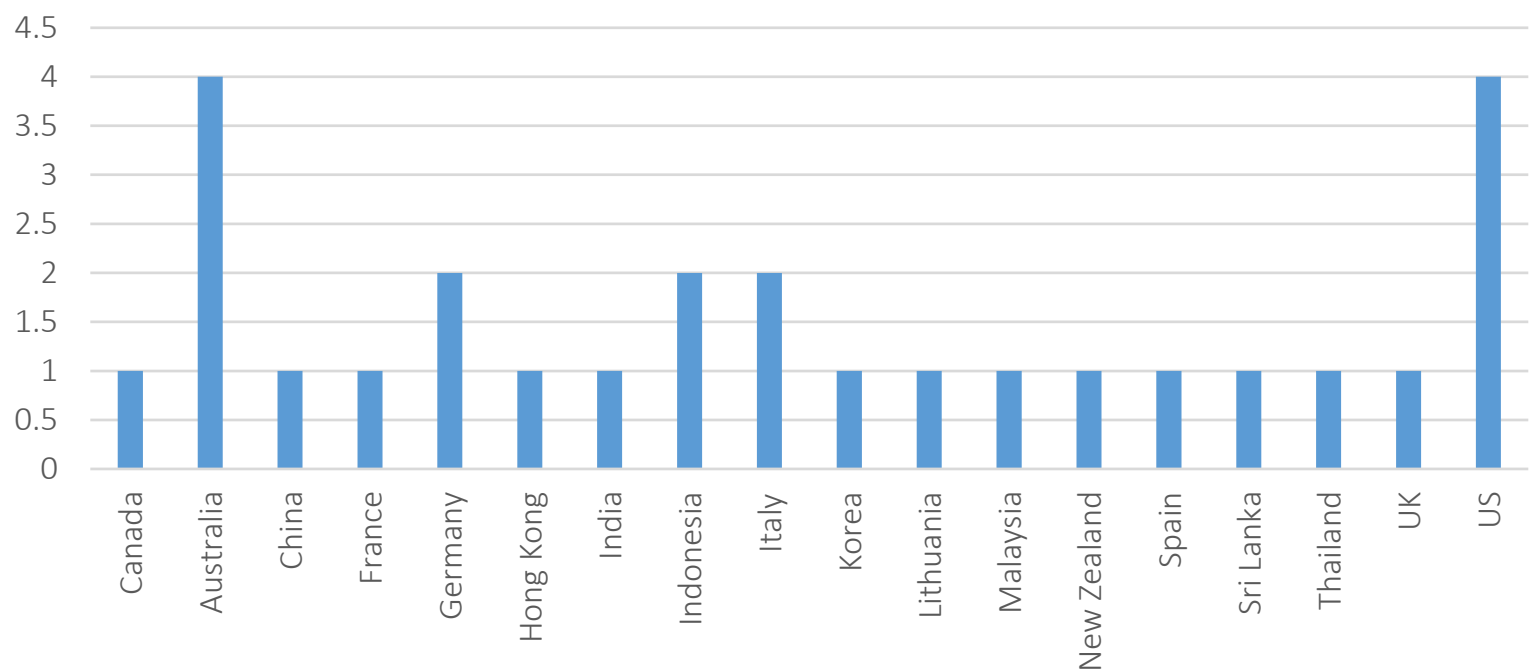

Figure 8. Country of origin 
Table 4. Research topics

\begin{tabular}{|c|c|c|c|}
\hline No. & Research topics & Articles & Percentage \\
\hline 1 & Sustainability discourse & 1 & $2.3 \%$ \\
\hline 2 & A credibility gap & 1 & $2.3 \%$ \\
\hline 3 & Citizen science & 1 & $2.3 \%$ \\
\hline 4 & Comprehensiveness of SR & 2 & $4.5 \%$ \\
\hline 5 & Corporate governance of SR & 5 & $11.4 \%$ \\
\hline 6 & Corporate sustainability accounting information systems & 1 & $2.3 \%$ \\
\hline 7 & Quality of SR & 2 & $4.5 \%$ \\
\hline 8 & Disclosure topics & 1 & $2.3 \%$ \\
\hline 9 & Environmental Orientation & 1 & $2.3 \%$ \\
\hline 10 & Factors influencing SR & 5 & $11.4 \%$ \\
\hline 11 & Impact of SR on firm performance/business performance & 2 & $4.5 \%$ \\
\hline 12 & Impression Management & 2 & $4.5 \%$ \\
\hline 13 & Online SR & 1 & $2.3 \%$ \\
\hline 14 & Paradoxes in sustainability & 1 & $2.3 \%$ \\
\hline 15 & SR preparers & 2 & $4.5 \%$ \\
\hline 16 & Readability of SR & 1 & $2.3 \%$ \\
\hline 17 & Real-life SR & 1 & $2.3 \%$ \\
\hline 18 & Reflection on social and environmental accounting & 1 & $2.3 \%$ \\
\hline 19 & SME'S & 1 & $2.3 \%$ \\
\hline 20 & Stakeholder engagement & 2 & $4.5 \%$ \\
\hline 21 & Sustainability assurance & 2 & $4.5 \%$ \\
\hline 22 & Sustainability performance & 1 & $2.3 \%$ \\
\hline 23 & Sustainability restatements & 1 & $2.3 \%$ \\
\hline 24 & SR practices and processes & 2 & $4.5 \%$ \\
\hline 25 & Diffusion of SR & 1 & $2.3 \%$ \\
\hline 26 & Compliance SR & 1 & $2.3 \%$ \\
\hline 27 & The state of SR & 1 & $2.3 \%$ \\
\hline 28 & Transparency of SR & 1 & $2.3 \%$ \\
\hline TOTAL & & 44 & $100.0 \%$ \\
\hline
\end{tabular}

(2018), Crifo et al. (2019), Hussain et al. (2018), Amidjaya and Widagdo (2019), and Jamil et al. (2020). Meanwhile, researchers who identify the factors influencing SR are Al-Shaer and Zaman (2019), Dong et al. (2020), Drempetic et al. (2020), and Montecalvo et al. (2018).

In this research period, 2015-2020, it can be seen that SR topics are more diverse than in the previous period. The diversity of these topics shows that there has been a development in researchers' mindset towards SR topics. If Hahn and Kühnen (2013) identify that governance is the primary concern of SR research in the period 1999-2011, the focus of SR research in 2015-2020 does not only discuss the factors that influence SR or the impact of SR practice. However, it has expanded to process, dissemination, readability, compliance, stakeholder engagement, and assurance. This finding suggests that as a relatively new issue, SR research offers a broader research niche for researchers in this field.

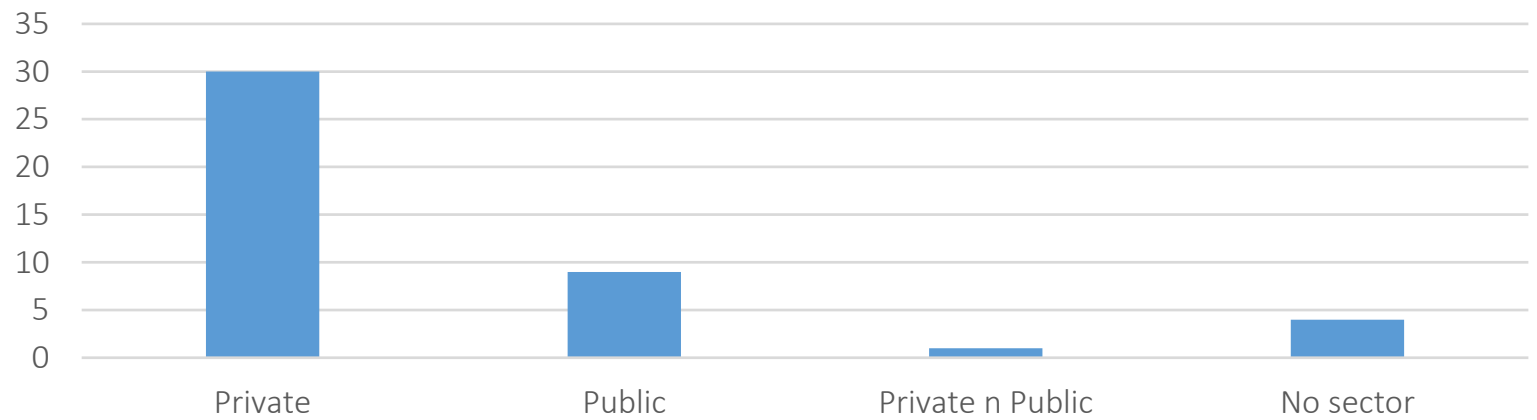

Figure 9. Research sector 


\subsection{Research sector}

Most recent research on social and environmental reporting has focused on the private sector. Previous research on SR has examined publication of company annual reports, but few studies have been reported in the public sector. According to Argento et al. (2019), apart from their relevance to the public sector, accounting and accountability for sustainability have not received much research attention.

The task of public sector organizations is to provide services that affect the quality of people's lives. For this reason, public organizations are expected to show responsible behavior to maintain the sustainability of future generations (Dumay et al., 2010). Therefore, public sector organizations' transparency is highly expected to indicate accountability by reporting their financial and non-financial performance (Grossi \& Steccolini, 2014).

30 articles (seventy-five percent) focused on the private sector, 8 articles (22.5 percent) on the public sector, and the remaining 2.5 percent discussed SR in private and public sectors, while 4 articles are conceptual articles that do not specifically discuss a particular sector. All the eight papers that focus on the public sector are research in developed countries such as Australia, the USA, Germany, Italy, Hong Kong, Spain, New Zealand, and other European countries. The public sector that concerns SR researchers includes universities (Klußmann et al., 2019; Sassen \& Azizi, 2018; Sepasi et al., 2019; An et al., 2019), state-owned enterprises (Larrinaga et al., 2018; Montecalvo et al., 2018), and NGOs (Gazzola et al., 2019).

\subsection{The future for SR research}

This section answers the third research question, "What is the future for SR research?". There are several worthwhile pursuits in sustainability accounting and reporting research such as SR preparers, SMEs, sustainability assurance, sustainable restatement, diffusion of SR, and topics frequently researched, such as SR influencing factors, SR compliance, SR performance, and SR quality. Based on the research object, research on SR in the future should start looking at sustainability in the public sector and SMEs, considering that not many previous studies have focused on these two objects.

The public sector is considered as a servant in the context of social and environmental problems. The main objective of public sector organizations (PSOs) is to implement public policies and support social welfare (Kaur \& Lodhia, 2018). The roles and responsibilities of the public sector are closely related to the sustainability agenda. Mostly since the countries of this world agreed on seventeen sustainable development goals (Bebbington \& Unerman, 2018), the next SR researcher should explore the sustainability research niche. While various SR studies have focused more on large companies, SMEs also deserve researchers' attention. What is the role of SMEs in sustainability, or what form of SR is appropriate for SMEs can be new research opportunities for SR researchers.

According to Safari and Areeb (2020), few studies examine the perceptions of report makers in the context of sustainability reporting. Therefore, this issue could become a niche for future research. Researchers can analyze the perceptions of report makers about the quality and challenges in preparing sustainability reports.

The restatement of the SR report is also an interesting issue for future SR researchers. Compared to financial data, it is more likely that errors in sustainability reporting will occur and are less likely to be discovered before the report is published. The lack of reporting standards and ambiguous CFS guidelines allow providers to perform restatements. Restatement is useful for pinpointing problems in sustainability reporting and ensuring the credibility of the report.

GRI data (2020) shows that more and more companies in the world are making sustainability reports. These reports provide information on the company's sustainability performance aimed at stakeholders. Improving the quality and credibility of a sustainability report requires assurance from a competent and independent party. "Sustainability assurance is an emerging practice imbued with many choices, outcomes, and determinants, all of which would benefit from a better theoretical understanding of the assurance decision" (Al-Shaer \& Zaman, 2019, p. 3). 


\section{CONCLUSION}

This study systematically presents empirical research on sustainability reporting for the period 20152020 and provides an overview using a qualitative approach. It also describes and discusses various approaches used in the SR literature. The study has identified a sample of 44 studies related to sustainability reporting published in accounting journals published between 2015 and 2020. To the best of the authors' knowledge, this study is the most recent literature review that provides an overview of sustainability reporting research. This analysis differs from previous studies that focused on the keywords of sustainability reporting and sustainability report. This study is unlike the previous one, which combined CSR and SR terminology. Using this approach, it can be ascertained that this study provides an overview of current SR research.

This study has contributed to a recent summary of sustainability reporting research and provided interesting insights and recommendations for future research. Based on the systematic literature review, this study shows a significant development of SR research in terms of numbers, diversity of theories, methods, and study concerns over the last few years.

The period 2015-2020 saw an increase in SR research, especially since 2018, which used both qualitative and quantitative paradigms. The SR study uses a variety of research methods, especially content analysis, case studies and semi-structured interviews. There is also a method that is rarely encountered, namely the world cafe approach. Stakeholder and legitimacy theory is still the main theory that is widely used in explaining SR, but various theories such as contingency, institutional, signaling, agency, ideology of number, paradox theory are also used in explaining the SR reality. Some studies use more than one theory to explain SR. The SR research scope consists of international, national and case studies. Research on SR during this period attracted more researchers from developed countries than from developing countries.

Related to the topic, the researchers raised a wide variety of topics ranging from the quantity of disclosure, quality of disclosure, SR performance, readability, preparers and others, although the number of studies is still one or two. This indicates that there is still a wide niche for SR research topics that can be studied further. Of all studies on SR reviewed, generally more were conducted in the private sector, although there were few studies on SR in the public sector.

This paper has limitations that could serve a basis for improving future research. The dataset does not include research papers (e.g. conference papers or working papers). It was also concluded that the reliability of the results can be confirmed more using the SRL method than using traditional literature reviews. However, researchers' understandings and beliefs will greatly influence the interpretation of the results.

\section{AUTHOR CONTRIBUTIONS}

Conceptualization: Inten Meutia.

Data curation: Shelly F. Kartasari.

Formal analysis: Shelly F. Kartasari.

Funding acquisition: Shelly F. Kartasari.

Investigation: Shelly F. Kartasari.

Methodology: Inten Meutia.

Project administration: Inten Meutia.

Resources: Inten Meutia.

Software: Zulnaidi Yaacob.

Supervision: Zulnaidi Yaacob. 
Validation: Zulnaidi Yaacob.

Visualization: Zulnaidi Yaacob.

Writing - original draft: Inten Meutia.

Writing - reviewing \& editing: Zulnaidi Yaacob.

\section{REFERENCES}

1. Adams, C. A., \& Frost, G. R. (2008). Integrating sustainability reporting into management practices. Accounting Forum, 32(4), 288-302. https://doi. org/10.1016/j.accfor.2008.05.002

2. Adams, C. A., Muir, S., \& Hoque, Z. (2014). Measurement of sustainability performance in the public sector. Sustainability Accounting, Management and Policy Journal, 5(1), 4667. https://doi.org/10.1108/ SAMPJ-04-2012-0018

3. Aggarwal, P., \& Singh, A. K. (2019). CSR and sustainability reporting practices in India: an in-depth content analysis of top-listed companies. Social Responsibility Journal, 15(8), 10331053. https://doi.org/10.1108/SRJ03-2018-0078

4. Al-Shaer, H., \& Zaman, M. (2019). CEO Compensation and Sustainability Reporting Assurance: Evidence from the UK. Journal of Business Ethics, 158(1), 233-252. https://doi.org/10.1007/ s10551-017-3735-8

5. Alvesson, M., \& Sandberg, J. (2011). Generating Research Questions Through Problematization. Academy of Management Review, 36(2), 247-271. https://doi.org/10.5465/ amr.2009.0188

6. Amidjaya, P. G., \& Widagdo, A. K. (2019). Sustainability reporting in Indonesian listed banks: Do corporate governance, ownership structure and digital banking matter? Journal of Applied Accounting Research, 21(2), 231247. https://doi.org/10.1108/ JAAR-09-2018-0149

7. An, Y., Davey, H., Harun, H., Jin, Z., Qiao, X., \& Yu, Q. (2019). Online sustainability reporting at universities: the case of Hong Kong. Sustainability Accounting,
Management and Policy Journal, 11(5), 887-901. https://doi. org/10.1108/SAMPJ-06-2018-0161

8. Anessi-Pessina, E., Barbera, C., Sicilia, M., \& Steccolini, I. (2016). Public sector budgeting: a European review of accounting and public management journals. Accounting, Auditing \& Accountability Journal, 29(3), 491-519. https://doi.org/10.1108/ AAAJ-11-2013-1532

9. Anunciação, P. F., Brasil, D. X., Marques, J. A., Matias, A. P. N., \& Garcia, C. P. (2017). Sustainability Reporting. International Journal of Sustainable Economies Management, 5(4), 10-24. https:// doi.org/10.4018/ijsem.2016100102

10. Arayssi, M., Dah, M., \& Jizi, M. (2016). Women on boards, sustainability reporting and firm performance. Sustainability Accounting, Management and Policy Journal, 7(3), 376401. https://doi.org/10.1108/ SAMPJ-07-2015-0055

11. Archel, P., Husillos, J., Larrinaga, C., \& Spence, C. (2009). Social disclosure, legitimacy theory and the role of the state. Accounting, Auditing \& Accountability Journal, 22(8), 1284-1307. https://doi. org/10.1108/09513570910999319

12. Argento, D., Grossi, G., Persson, K., \& Vingren, T. (2019). Sustainability disclosures of hybrid organizations: Swedish state-owned enterprises. Meditari Accountancy Research, 27(4), 505-533. https://doi.org/10.1108/ MEDAR-07-2018-0362

13. Bae, S., Masud, M., \& Kim, J. (2018). A Cross-Country Investigation of Corporate Governance and Corporate Sustainability Disclosure: A Signaling Theory Perspective. Sustainability, 10(8), 2611. https:// doi.org/10.3390/su10082611
14. Bebbington, J., \& Unerman, J. (2018). Achieving the United Nations Sustainable Development Goals. Accounting, Auditing \& Accountability Journal, 31(1), 2-24. https://doi.org/10.1108/AAAJ-052017-2929

15. Bebbington, J., LarrinagaGonzález, C., \& Moneva-Abadía, J. M. (2008). Legitimating reputation/the reputation of legitimacy theory. Accounting, Auditing \& Accountability Journal, 21(3), 371-374. https://doi. org/10.1108/09513570810863969

16. Bebbington, J., Russell, S., \& Thomson, I. (2017). Accounting and sustainable development: Reflections and propositions. Critical Perspectives on Accounting, 48, 21-34. https://doi.org/10.1016/j. cpa.2017.06.002

17. Boiral, O., Heras-Saizarbitoria, I., \& Brotherton, M. C. (2019). Assessing and Improving the Quality of Sustainability Reports: The Auditors' Perspective. Journal of Business Ethics, 155(3), 703-721. https://doi.org/10.1007/s10551017-3516-4

18. Bowen, H. R. (2013). Social responsibilities of the businessman. University of Iowa Press. Retrieved from https://www.uipress.uiowa.edu/ books/9781609381967/the-socialresponsibilities-of-the-businessman

19. Bracci, E., Papi, L., Bigoni, M., Gagliardo, E. D., \& Bruns, H.-J. (2019). Public value and public sector accounting research: a structured literature review. Journal of Public Budgeting, Accounting \& Financial Management, 31(1), 103-136. https://doi.org/10.1108/JPBAFM-07-2018-0077

20. Byun, H., \& Kim, T. H. (2017). Identity Claims and Diffusion of 
Sustainability Report: Evidence from Korean Listed Companies, 2003-2010. Journal of Business Ethics, 140(3), 551-565. https://doi. org/10.1007/s10551-015-2669-2

21. Carroll, A. B. (2009). A History of Corporate Social Responsibility. In A. Crane, D. Matten, A. McWilliams, J. Moon, \& D. S. Siegel (Eds.), The Oxford Handbook of Corporate Social Responsibility (Vol. 1). Oxford University Press. https:// doi.org/10.1093/oxfordhb/9780199211593.003.0002

22. Crifo, P., Escrig-Olmedo, E., \& Mottis, N. (2019). Corporate Governance as a Key Driver of Corporate Sustainability in France: The Role of Board Members and Investor Relations. Journal of Business Ethics, 159(4), 1127-1146. https://doi.org/10.1007/s10551018-3866-6

23. Dienes, D., Sassen, R., \& Fischer, J. (2016). What are the drivers of sustainability reporting? A systematic review. Sustainability Accounting, Management and Policy Journal, 7(2), 154189. https://doi.org/10.1108/ SAMPJ-08-2014-0050

24. Dissanayake, D., Tilt, C., \& Qian, W. (2019). Factors influencing sustainability reporting by Sri Lankan companies. Pacific Accounting Review, 31(1), 84-109. https://doi.org/10.1108/PAR-102017-0085

25. Dong, S., Xu, L., \& McIver, R. (2020). China's financial sector sustainability and "green finance" disclosures. Sustainability Accounting, Management and Policy Journal, 12(2), 353384. https://doi.org/10.1108/ SAMPJ-10-2018-0273

26. Drempetic, S., Klein, C., \& Zwergel, B. (2020). The Influence of Firm Size on the ESG Score: Corporate Sustainability Ratings Under Review. Journal of Business Ethics, 167(2), 333-360. https://doi. org/10.1007/s10551-019-04164-1

27. Dumay, J., Bernardi, C., Guthrie, J., \& Demartini, P. (2016). Integrated reporting: A structured literature review. Accounting Forum, 40(3), 166-185. https://doi.org/10.1016/j. accfor.2016.06.001
28. Dumay, J., Guthrie, J., \& Farneti, F. (2010). GRI sustainability reporting guidelines for public and third sector organizations: A critical review. Public Management Review, 12(4), 531-548. https:// doi.org/10.1080/14719037.2010. 496266

29. Farneti, F., Casonato, F., Montecalvo, M., \& de Villiers, C. (2019). The influence of integrated reporting and stakeholder information needs on the disclosure of social information in a state-owned enterprise. Meditari Accountancy Research, 27(4), 556-579. https://doi.org/10.1108/ MEDAR-01-2019-0436

30. Frynas, J. G., \& Yamahaki, C. (2016). Corporate social responsibility: review and roadmap of theoretical perspectives. Business Ethics: A European Review, 25(3), 258-285. https://doi.org/10.1111/beer.12115

31. Gazzola, P., Amelio, S., Papagiannis, F., \& Michaelides, Z. (2019). Sustainability reporting practices and their social impact to NGO funding in Italy. Critical Perspectives on Accounting. https:// doi.org/10.1016/j.cpa.2019.04.006

32. Grossi, G., \& Steccolini, I. (2014). Accounting for public governance. Qualitative Research in Accounting and Management, 11(2), 86-91. https://doi.org/10.1108/QRAM04-2014-0031

33. Hahn, R., \& Kühnen, M. (2013). Determinants of sustainability reporting: a review of results, trends, theory, and opportunities in an expanding field of research. Journal of Cleaner Production, 59, 5-21. https://doi.org/10.1016/j. jclepro.2013.07.005

34. Hahn, T., Figge, F., Pinkse, J., \& Preuss, L. (2018). A Paradox Perspective on Corporate Sustainability: Descriptive, Instrumental, and Normative Aspects. Journal of Business Ethics, 148(2), 235-248. https://doi. org/10.1007/s10551-017-3587-2

35. Higgins, C., Tang, S., \& Stubbs, W. (2020). On managing hypocrisy: The transparency of sustainability reports. Journal of Business Research, 114, 395-407. https://doi. org/10.1016/j.jbusres.2019.08.041
36. Hsueh, J. W. J. (2018). Governance Structure and the Credibility Gap: Experimental Evidence on Family Businesses' Sustainability Reporting. Journal of Business Ethics, 153(2), 547-568. https://doi. org/10.1007/s10551-016-3409-y

37. Hussain, N., Rigoni, U., \& Orij, R. P. (2018). Corporate Governance and Sustainability Performance: Analysis of Triple Bottom Line Performance. Journal of Business Ethics, 149(2), 411-432. https://doi. org/10.1007/s10551-016-3099-5

38. Ismaeel, M., \& Zakaria, Z. (2020). Perception of preparers of sustainability reports in the Middle East: Contrasting between local and global. Meditari Accountancy Research, 28(1), 89-116. https://doi.org/10.1108/ MEDAR-03-2019-0459

39. Jamil, A., Mohd Ghazali, N. A., \& Puat Nelson, S. (2020). The influence of corporate governance structure on sustainability reporting in Malaysia. Social Responsibility Journal. https://doi. org/10.1108/SRJ-08-2020-0310

40. Journeault, M., Levant, Y., \& Picard, C.-F. (2020). Sustainability performance reporting: A technocratic shadowing and silencing. Critical Perspectives on Accounting, 74, 102145. https://doi. org/10.1016/j.cpa.2019.102145

41. Kaelbling, L. P., Littman, M. L., \& Moore, A. W. (1996). Reinforcement Learning: A Survey. The SAGE Handbook of Organizational Research Methods. Retrieved from http://arxiv.org/ abs/cs/9605103

42. Kaur, A., \& Lodhia, S. (2018). Stakeholder engagement in sustainability accounting and reporting: A study of Australian local councils. Accounting, Auditing and Accountability Journal, 31(1), 338-368. https://doi. org/10.1108/AAAJ-12-2014-1901

43. Khlif, H., \& Achek, I. (2017). Gender in accounting research: a review. Managerial Auditing Journal, 32(6), 627-655. https://doi. org/10.1108/MAJ-02-2016-1319 
44. Klußmann, C., Sassen, R., \& Gansel, E. (2019). Structural key factors of participatory sustainability reporting for universities. International Journal of Sustainability in Higher Education, 20(6), 10801098. https://doi.org/10.1108/ IJSHE-08-2018-0139

45. Kolk, A. (2004). A decade of sustainability reporting: Developments and significance. International Journal of Environment and Sustainable Development, 3(1). https://doi. org/10.1504/IJESD.2004.004688

46. KPMG \& UNEP. (2006). Carrots and Sticks for Starters: Current trends and approaches in Voluntary and Mandatory Standards for Sustainability Reporting. Retrieved from https://www.carrotsandsticks.net/media/ey3jsm5o/ carrots-sticks-2006.pdf

47. KPMG. (2008). Sustainability Report Study. Business and the Environment, 19(3), 182-198.

48. Lanis, R., \& Richardson, G. (2012). Corporate social responsibility and tax aggressiveness: a test of legitimacy theory. Accounting, Auditing \& Accountability Journal, 26(1), 75-100. https://doi. org/10.1108/09513571311285621

49. Larrinaga, C., Luque-Vilchez, M., \& Fernández, R. (2018). Sustainability accounting regulation in Spanish public sector organizations. Public Money and Management, 38(5), 345-354. https://doi.org/10.1080/09540962. 2018.1477669

50. Larrinaga-Gonzalez, C. (2007). Sustainability reporting: insights from neo-institutional theory. In J. Unerman, B. O'dwyer, \& J. Bebbington (Eds.), Sustainability Accounting and Accountability. London: Routledge.

51. Li, Y., Zhang, J., \& Foo, C.-T. (2013). Towards a theory of social responsibility reporting. Chinese Management Studies, 7(4), 519534. https://doi.org/10.1108/CMS09-2013-0167

52. Lynch, M., Lynch, N., \& Casten, D. (2014). The Expanding Use of Sustainability Reporting. The CPA
Journal, 84(3). Retrieved from https://digitalcommons.bryant. edu/acc_jou/62/

53. Majoch, A. A. A., Hoepner, A. G. F., \& Hebb, T. (2017). Sources of Stakeholder Salience in the Responsible Investment Movement: Why Do Investors Sign the Principles for Responsible Investment? Journal of Business Ethics, 140(4), 723-741. https://doi. org/10.1007/s10551-016-3057-2

54. Massa, L., Farneti F., \& Scappini, B. (2015). Developing a sustainability report in a small to medium enterprise: process and consequences. Meditari Accountancy Research, 23(1), 62-91. http://dx.doi.org/10.1108/MEDAR-02-2014-0030

55. Massaro, M., Dumay, J., \& Guthrie, J. (2016). On the shoulders of giants: undertaking a structured literature review in accounting. Accounting, Auditing and Accountability Journal, 29(5), 767-801. https://doi.org/10.1108/ AAAJ-01-2015-1939

56. Meutia, I., Mustika, S., \& Adam, M. (2018). Cultural Relevance to Sustainability Reporting in Asian and European Banking. Journal of Accounting, Business and Finance Research, 4(1), 9-19. https://doi. org/10.20448/2002.41.9.19

57. Michelon, G., Patten, D. M., \& Romi, A. M. (2019). Creating Legitimacy for Sustainability Assurance Practices: Evidence from Sustainability Restatements. European Accounting Review, 28(2) 395-422. https://doi.org/10.1080/0 9638180.2018 .1469424

58. Millar, E., \& Searcy, C. (2020). The presence of citizen science in sustainability reporting. Sustainability Accounting, Management and Policy Journal, 11(1), 31-64. https://doi. org/10.1108/SAMPJ-01-2019-0006

59. Milne, M. J., \& Gray, R. (2013). W(h)ither Ecology? The Triple Bottom Line, the Global Reporting Initiative, and Corporate Sustainability Reporting. Journal of Business Ethics, 118, 13-29. https://doi. org/10.1007/s10551-012-1543-8
60. Montecalvo, M., Farneti, F., \& de Villiers, C. (2018). The potential of integrated reporting to enhance sustainability reporting in the public sector. Public Money and Management, 38(5), 365-374. https://doi.org/10.1080/09540962. 2018.1477675

61. Ong, T., \& Djajadikerta, H. G. (2018). Corporate governance and sustainability reporting in the Australian resources industry: an empirical analysis. Social Responsibility Journal, 16(1), 1-14. Retrieved from https://ro.ecu.edu. au/ecuworkspost2013/8269/

62. Petcharat, N., \& Zaman, M. (2019) Sustainability reporting and integrated reporting perspectives of Thai-listed companies. Journal of Financial Reporting and Accounting, 17(4), 671-694. https:// doi.org/10.1108/JFRA-09-20180073

63. Rezaee, Z. (2016). Business sustainability research: A theoretical and integrated perspective. Journal of Accounting Literature, 36, 48-64. https://doi. org/10.1016/j.acclit.2016.05.003

64. Safari, M., \& Areeb, A. (2020). A qualitative analysis of GRI principles for defining sustainability report quality: an Australian case from the preparers' perspective. Accounting Forum, 44(4), 344-375. https://doi.org/10. 1080/01559982.2020.1736759

65. Sassen, R., \& Azizi, L. (2018). Assessing sustainability reports of US universities. International Journal of Sustainability in Higher Education, 19(7), 11581184. https://doi.org/10.1108/ IJSHE-06-2016-0114

66. Schnepp, G. J., \& Bowen, H. R. (1954). Reviewed Work: Social Responsibilities of the Businessman by Howard R. Bowen. The American Catholic Sociological Review, 15(1), 42. https://doi. org/10.2307/3708003

67. Sepasi, S., Braendle, U., \& Rahdari, A. H. (2019). Comprehensive sustainability reporting in higher education institutions. Social Responsibility Journal, 15(2), 155170. https://doi.org/10.1108/SRJ01-2018-0009 
68. Shabana, K. M., Buchholtz, A. K., \& Carroll, A. B. (2017). The Institutionalization of Corporate Social Responsibility Reporting. Business and Society, 56(8), 1107-1135. https://doi. org/10.1177/0007650316628177

69. Soh, D. S. B. (2014). Sustainability Reporting and Assurance: A Historical Analysis on a WorldWide Phenomenon. Social and Environmental Accountability Journal, 34(2), 125-125. https:// doi.org/10.1080/096916 0x.2014.938484

70. Spence, C., Husillos, J., \& Correa-Ruiz, C. (2010). Cargo cult science and the death of politics: A critical review of social and environmental accounting research. Critical Perspectives on Accounting, 21(1), 76-89. https:// doi.org/10.1016/j.cpa.2008.09.008

71. Stocker, F., de Arruda, M. P., de Mascena, K. M. C., \& Boaventura, J. M. G. (2020). Stakeholder engagement in sustainability reporting: A classification model. Corporate Social Responsibility and Environmental Management, 27(5), 2071-2080. https://doi. org/10.1002/csr.1947

72. Talbot, D., \& Boiral, O. (2018). GHG Reporting and Impression
Management: An Assessment of Sustainability Reports from the Energy Sector. Journal of Business Ethics, 147(2), 367-383. https:// doi.org/10.1007/s10551-0152979-4

73. Usmani, M., Davison, J., \& Napier, C. J. (2020). The production of stand-alone sustainability reports: visual impression management, legitimacy and "functional stupidity." Accounting Forum, 44(4), 315-343. https://doi.org/10 $.1080 / 01559982.2020 .1782566$ 